\section{Memantin uten effekt ved Downs syndrom}

Personer med Downs syndrom utvikler ofte demens i tidlig alder, men memantin har ikke effekt på kognisjon eller atferd. Det viser en ny studie.

Trisomi 21 påvirker metabolismen av både amyloid og tau, som også er sentrale for utviklingen av Alzheimers sykdom. Alle personer med Downs syndrom utvikler nevropatologiske forandringer som ved Alzheimers sykdom etter 40-årsalderen, og dette ledsages av en reduksjon av mental funksjonsevne. Som ved andre former for demens utvikler også personer med Downs syndrom og demens ofte psykiske og atferdsmessige endringer knyttet til demens.

Dessverre finnes det få eller ingen anerkjente behandlingsmetoder for demens ved Downs syndrom. Enkelte mindre studier tyder på at kolinesterasehemmere som donepezil er bedre enn placebo også for denne pasientgruppen, mens det ikke finnes undersøkelser av effekten av memantin.

Målet med denne studien var å studere effekten av memantin på kognitiv funksjon og atferd hos personer med Downs syndrom som var 40 år eller eldre med eller uten demens (1). Studien var placebokontrollert, randomisert og omfattet 193 personer, hvorav ca. $85 \%$ ble undersøkt etter 52 uker. Forsøkspersonene ble regelmessig undersøkt med to standardiserte og validerte måleinstrumenter.

- Vi fant at memantin ikke hadde effekt på kognisjon eller atferd i denne gruppen, og heller ikke på global funksjonsevne, sier Dag Aarsland ved Stavanger universitetssjukehus. Heller ikke når bare deltakere med demens ble inkludert, viste analysene signifikante forskjeller mellom gruppene. Den negative konklusjonen støttes av at de ikke-signifikante forskjellene som ble påvist var til fordel for placebo. Det ble heller ikke vist endring i konsentrasjon av betaamyloidpeptid i plasma mellom de to gruppene.

- At memantin ikke er effektivt i behandling eller forebygging av demens ved Downs syndrom, tyder på at de underliggende mekanismene for demens og alzheimerforandringer er forskjellige hos personer med og uten Downs syndrom, sier Aarsland.

\section{Forskergruppen}

Studien var initiert og ledet av professor Clive Ballard ved King's College London, som også er forskningsdirektør ved UK

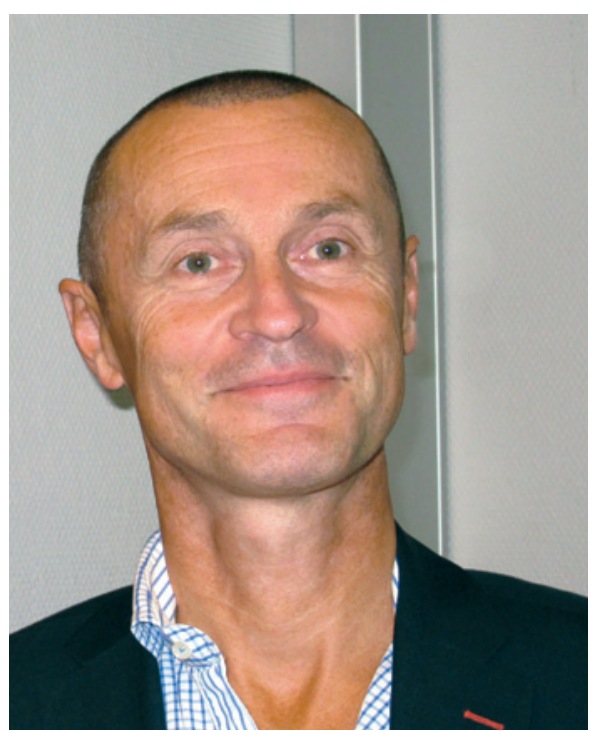

Artikkelens eneste norske forfatter, Dag Aarsland. Foto privat

Alzheimer's Association. Ballard er gjesteprofessor ved Regionalt senter for eldremedisin og samhandling ved Stavanger universitetssjukehus og har i mange år samarbeidet med forskergruppen i Stavanger. Samarbeidet har særlig dreid seg om andre demensformer enn Alzheimers sykdom, som demens med lewylegemer og Parkinsons sykdom. I tillegg til tre sentre i England var fagpersoner ved Stavanger universitetssjukehus og habiliteringstjenesten i Helse Bergen aktivt involvert i datainnsamlingen.

\section{Erlend Hem}

erlend.hem@medisin.uio.no

Tidsskriftet

\section{Litteratur}

1. Hanney M, Prasher V. Williams N et al. Memantine for dementia in adults older than 40 years with Down's syndrome (MEADOWS): a randomised, double-blind, placebo-controlled trial. Lancet 2012; 379: 528-36.
Ordforklaringer

DAMES: Standardisert graderingsskala av kognitive funksjoner til bruk hos personer med Downs syndrom

ABS: Adaptive Behavior Scale; et strukturert komparentbasert kartleggingsverktøy for daglig funksjonsevne og utfordrende atferd.

Memantin: Antidemensmedisin, partiell NMDA-glutamat-reseptorantagonist som er godkjent til behandling av moderat og alvorlig Alzheimers sykdom.

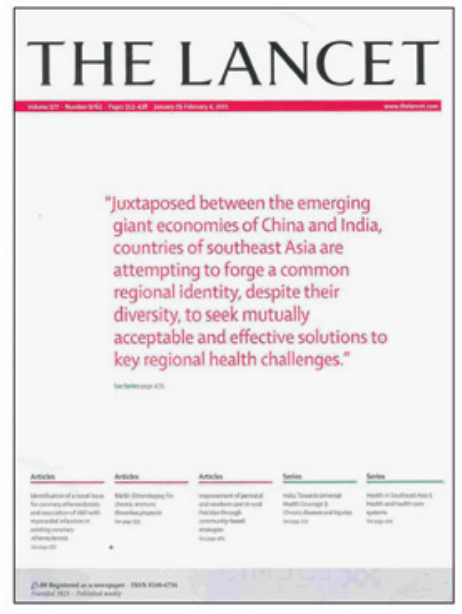

Artikkelen ble publisert 11.2. $2012 \mathrm{i}$ The Lancet, som regnes som en av de «fem store» innen medisinsk publisering ved siden av New England Journal of Medicine, JAMA, Annals of Internal Medicine og BMJ 